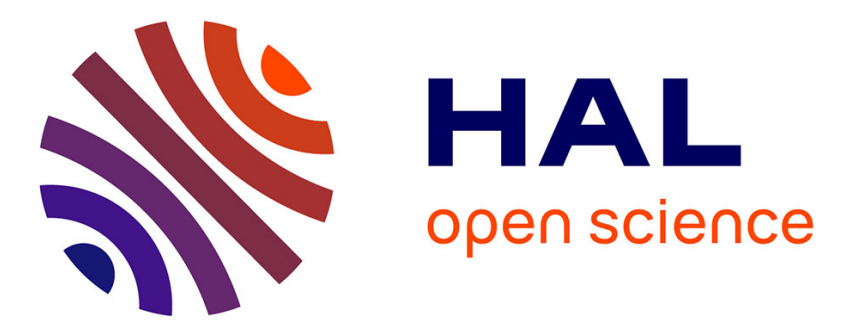

\title{
C4 grass functional traits are correlated with biotic and abiotic gradients in an African savanna.
}

Yanis Bouchenak-Khelladi, E.C. February, G.A. Verboom, F.C. Boucher

\section{To cite this version:}

Yanis Bouchenak-Khelladi, E.C. February, G.A. Verboom, F.C. Boucher. C4 grass functional traits are correlated with biotic and abiotic gradients in an African savanna.. Plant Ecology, 2020, 221 (4), pp.241-254. 10.1007/s11258-020-01007-2 . hal-02542111

\section{HAL Id: hal-02542111 \\ https://hal.science/hal-02542111}

Submitted on 26 May 2021

HAL is a multi-disciplinary open access archive for the deposit and dissemination of scientific research documents, whether they are published or not. The documents may come from teaching and research institutions in France or abroad, or from public or private research centers.
L'archive ouverte pluridisciplinaire HAL, est destinée au dépôt et à la diffusion de documents scientifiques de niveau recherche, publiés ou non, émanant des établissements d'enseignement et de recherche français ou étrangers, des laboratoires publics ou privés.

\section{(c)(1)}

Distributed under a Creative Commons Attribution| 4.0 International License 


\title{
$\mathrm{C}_{4}$ grass functional traits are correlated with biotic and abiotic gradients in an African savanna
}

\author{
Y. Bouchenak-Khelladi 1 - E. C. February • G. A. Verboom • F. C. Boucher
}

\begin{abstract}
Savanna is a species-rich biome, that includes many modern mammal lineages and $\mathrm{C}_{4}$ grass (Poaceae) species. The greater productivity and grazing pressure associated with savannas is likely attributable to the foliar traits of the grasses they support. Thus, it is important to understand the complex relationships between the abiotic environment, foliar attributes and the floristic composition of savanna grasses, and the supported grazer densities. We sampled 37 grass communities in the Kruger
\end{abstract}

Y. Bouchenak-Khelladi ( $\square)$

Institute of Systematic and Evolutionary Botany, University of Zurich, Zollikertrasse 107, 8008 Zurich, Switzerland

e-mail: boucheny@tcd.ie

Y. Bouchenak-Khelladi

Université de Bourgogne Franche-Comté, UMR

Biogéosciences CNRS 6282, 6 Boulevard Gabriel,

21000 Dijon, France

E. C. February - G. A. Verboom - F. C. Boucher Department of Biological Sciences, University of Cape

Town, Private Bag, Rondebosch 7701, South Africa
National Park (South Africa) across three soil types and along a rainfall gradient and found that these communities lack strong phylogenetic structure. We then measured specific leaf area and leaf tensile strength for 384 individuals representing 66 species and found that both traits were strongly phylogenetically structured and associated with both rainfall and soil type. Finally, we found that grazer densities in the Park are correlated with the foliar traits of the associated grass communities, but the resolution of our data do not allow for a thorough analysis of this association. Our results demonstrate the complex interactions between climate, soils and grazer densities relative to $\mathrm{C}_{4}$ grass functional traits.

\author{
F. C. Boucher \\ Department of Botany and Zoology, University of \\ Stellenbosch, Private Bag X1, Matieland 7602, South \\ Africa \\ F. C. Boucher \\ Université Grenoble Alpes, Université Savoie Mont \\ Blanc, CNRS, LECA, 38000 Grenoble, France
}


Keywords African savanna $\cdot \mathrm{C}_{4}$ grasses $\cdot$ Grazer density $\cdot$ Leaf tensile strength $\cdot$ SLA

\section{Introduction}

Savanna ecosystems cover around $20 \%$ of the global land area and are characterized by both a high diversity of ungulates and $\mathrm{C}_{4}$ grasses (Turpie and Crow 1994; Lehmann and Parr 2016). These ecosystems are of socioeconomic importance because they support a substantial portion of the world's population and most of its rangeland and herbivore biomass (Sankaran et al 2005; Scholes and Archer 1997). It is therefore important to develop a sound mechanistic understanding of the processes underpinning the complex mechanisms that drive and maintain the tremendous biological diversity within these ecosystems.

Either directly for herbivores or indirectly for carnivores, large mammals depend on plant community composition (Augustine and McNaughton 1998). Plant communities are in turn influenced by abiotic environmental gradients. In savannas, for example, there is a strong, positive, linear relationship between vegetation biomass and annual precipitation (McNaughton and Georgiadis 1986). A potential increase in vegetation biomass is, however, controlled by a combination of both herbivory and fire to around $700 \mathrm{~mm}$ MAP after which fire takes over as the dominant determinant (Sankaran et al. 2005; Archibald and Hempson 2016). It has, however, also been demonstrated that there is an increase in herbivore biomass as MAP increases to around $700 \mathrm{~mm}$ (East 1984; Grant and Scholes 2006; Cromsigt et al. 2009; Hempson et al. 2015; Archibald and Hempson 2016). At our study site in the Kruger National Park (South Africa), the highest rainfall is around $750 \mathrm{~mm}$ in the south of the Park (Holdo et al 2018) and as a result we would expect herbivore biomass to increase as rainfall increases. Intensive grazing is, however, a feature of African savanna ecosystems, with grass consumption positively and linearly related to plant productivity (Augustine et al. 2003). In addition, presumably because of high precipitation fosters, high grass productivity, and standing biomass (February et al. 2013), these conditions also promote high fire frequencies (Archibald and Hempson 2016).
Tropical savannas are often associated with nutrient poor soils (Scholes 1990; Medina 1993), especially in higher rainfall areas such as in West Africa and South America (Februrary et al. 2019). Where rainfall amount may be associated with soil nutrient status, a fundamental feature of most savannas is heterogenous soil fertility (Medina 1993; Venter et al. 2003).The greater productivity and grazing pressure associated with high-rainfall, high-nutrient savanna sites are likely attributable to the foliar quality of the grasses they support. Low nutrient and moisture availability are both thought to select for leaves having a higher tissue density than those from moister and/or more fertile sites (Wright et al. 2001; Wright and Westoby 2003; Ordoñez et al. 2009). High-density leaves offer clear benefits in resource-limited sites, since their greater durability and tensile strength increases leaf longevity (Wright et al. 2001) and resistance to herbivory (Franks et al. 2008). By contrast, lowdensity leaves and despite rendering plants more palatable to herbivores (Cingolani et al. 2005), are generally beneficial in resource-rich sites since they facilitate rapid growth, thereby enhancing the competitive ability of plants as well as their ability to tolerate grazing (Cingolani et al. 2005). Such changes in foliar traits between communities experiencing different environmental conditions could be due to two radically different, but non-exclusive, processes: species turnover and within-species trait variation (Lepš et al. 2011). Many plant functional traits display significant phylogenetic signal, with closely related taxa having trait values that are generally more similar than expected by chance (Liu et al. 2015; Flores et al. 2014). In this context, there is reason to expect the environmental correlates of leaf traits to translate into floristic patterning with moist/fertile and dry/infertile environments favouring contrasting suites of lineages. There is some evidence of such patterning in savanna grasses, with the distributions of $\mathrm{C}_{4}$ grass subfamilies and tribes being predicted by contrasting environmental conditions (Visser et al. 2012) and grazing pressure (Hempson et al. 2015). In particular, where species of Andropogoneae dominate moist, infertile sites that experience limited grazing pressure but high fire frequencies, species of Chloridoideae dominate drier sites on richer soils with heavier grazing pressure and lower fire frequencies (Visser et al. 2012). Paniceae and Aristidoideae occupy intermediate positions, with mesic-adapted Paniceae responding positively to both 
fire and grazing, and arid-adapted Aristidoideae responding positively to grazing but not fire (Visser et al. 2012).

Against this background, we set out to examine the foliar attributes and floristic composition of savanna grass communities situated on sites of contrasting fertility and precipitation in the Kruger National Park, South Africa (KNP, hereafter). We tested the hypothesis that environmental gradients influence the phylogenetic composition and palatability of grass assemblages because low nutrient and moisture availability are both thought to select for leaves having a high tissue density and lower SLA than those from moister and/or more fertile sites (Wright et al. 2001; Wright and Westoby 2003), and that these in turn are linked to grazer densities. To address this, we measured two important leaf traits: specific leaf area (hereafter SLA), a key trait associated with leaf economics and lifespan that correlates strongly with environmental gradients (Wright et al. 2001), and leaf tensile strength, which is routinely used to determine the palatability of grass species (Martens and de V. Booysen 1968). We then assessed whether (i) there was a correlation between SLA and leaf tensile strength, (ii) phylogenetic signal in foliar traits resulted in grass lineages being non-randomly distributed locally, (iii) environmental variables influenced grass foliar attributes at the community level, and (iv) average grass foliar attributes at the community level correlated with grazer densities.

\section{Materials and methods}

Field sampling

Our study site is the $20,000 \mathrm{~km}^{2}$ Kruger National Park located in the north east of South Africa. Rainfall is distinctly seasonal with a wet season from October to May. Mean annual precipitation is lowest in the extreme north $(400 \mathrm{~mm})$ and highest at Pretoriuskop in the southwest $(750 \mathrm{~mm}$ ) (Holdo et al. 2018). Since herbivore densities also generally increase from North to South in the park, we expect herbivore biomass to increase as rainfall increases across the KNP. In February 2007, we sampled $37(10 \mathrm{~m} \times 10 \mathrm{~m})$ plots distributed across the whole KNP representing a wide range of climatic and geological settings (Fig. 1). For each plot we recorded the full list of grass species and determined the mean SLA and leaf tensile strength using fully formed whole fresh leaves from three distinct individuals of each species. SLA was determined using the protocol of Garnier et al. (2001), while leaf tensile strength was determined as the breaking tension per unit of leaf cross-sectional area (Martens and de V. Booysen 1968). The breaking tension of leaves was measured in the field using a standard tensilmeter (Martens and de V. Booysen 1968), while leaf cross-sectional area was estimated as the product of leaf thickness and width, respectively measured using a digital vernier calliper precise to $0.01 \mathrm{~mm}$ and a metal ruler precise to $0.5 \mathrm{~mm}$. Across all plots, we sampled a total of 384 individuals from 68 species, all from the subfamilies Aristidoideae, Chloridoideae and Panicoideae.

We also characterized each plot in terms of its geology, mean annual precipitation (MAP), and grazer density. Soils in the KNP reflect the underlying bedrock and can broadly be divided into basaltic soils in the east and, granitic soils in the west, with a narrow, intervening strip of shale-derived soils (Venter et al. 2003). Combined grazer densities of Buffalo (Syncerus caffer), Blue Wildebeest (Connochaetes taurinus), Waterbuck (Kobus elipsiprimnus), and White Rhino (Ceratotherium simum) were derived from aerial surveys conducted between 1987 and 1993 (Smit et al. 2007).

While zebra (Equus burchelli) is one of the most abundant herbivore in the park we did not include these in our analysis as they occurred in very low densities in our plots and we hypothesis that this is because they are distributed evenly across the landscape as they are neither short nor long grass specialists (Archibald et al. 2005). Densities were averaged over a $3 \mathrm{~km}$ buffer around plots to account for local anomalies and to smooth out spatial inaccuracies (Izak Smit pers. comm.). We used these data in the present study because these are the only data available based on a full aerial census of the KNP giving total counts of all animals with the precision needed for our study. From 1998 a line-transect method, using fixed wing aircraft, replaced the total count method (Kruger et al. 2008). This new census method gives population estimates for monitoring trends in animal numbers over time in each of four blocks, namely: the southern KNP (from the Crocodile to the Sabie River), the central KNP (from the Sabie to the Olifants River), the northern KNP (from the 


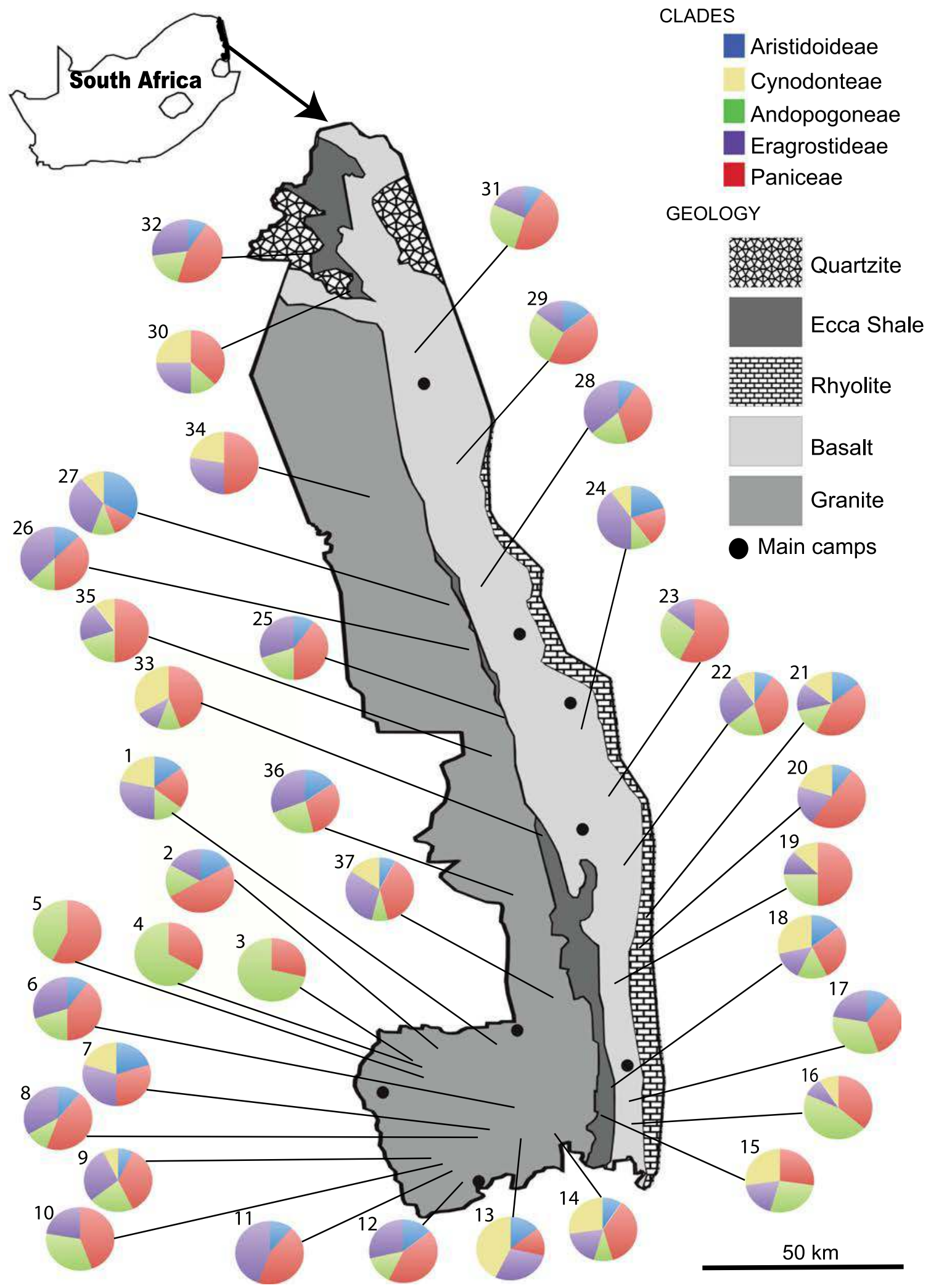


4Fig. 1 The location of the plots in the KNP with soil type and proportion of grass species in the communities according to taxonomy

Olifants to the Shingwedzi River), and the far northern KNP (from the Shingwedzi to the Limpopo River). We examined the relative abundance of herbivores within each of the four blocks and found that these have not changed substantially between 1998 and 2016 (see Supplementary Fig. S1). Analysis of variance, treating years as independent observations, identified the proportional abundance of grazers as differing significantly amongst blocks $\left(F_{3,32}=60.67, P<0.0001\right)$, with a Tukey post hoc identifying the southern and central KNP as being significantly different from the northern and far northern KNP in terms of grazer density. We use this result to justify our use of the precise aerial surveys done between 1987 and 1993.

Soil nutrient content

Our plots were intentionally located on the three major soil types in the KNP basalt, granite, and shale soils. Differences in the nutrient content of these soils have been previously determined by summing the concentrations of base cations (Venter 1990). These data show that the cation exchange capacity of granite soils along a catenal sequence ranges between 19 and 30 $\mathrm{me} / \mathrm{kg}$ at the top of the sequence, and between 36 and $155 \mathrm{me} / \mathrm{kg}$ at the bottom of the sequence. For the basaltic soils these values are higher, ranging from 241 and $301 \mathrm{me} / \mathrm{kg}$ at the top to 351 and $435 \mathrm{me} / \mathrm{kg}$ at the bottom of the sequence. Values for the shale soils are slightly higher than those of the granites ranging between 52 and $57 \mathrm{me} / \mathrm{kg}$ at the top of the sequence, to 82 and $188 \mathrm{me} / \mathrm{kg}$ at the bottom of the sequence (Venter 1990). What is important for our study is that these results show that the granite soils are generally less fertile than those derived from basalt and shale. It has also been demonstrated that nitrogen concentrations are highest in the basalt soils and lowest in the granite soils. These values range from $0.22 \%$ under trees to $0.17 \%$ away from trees on the basalt soils, and from $0.17 \%$ under trees to $0.08 \%$ away from trees on the granites (February and Higgins 2010).
Phylogeny

In order to assess phylogenetic structuring of communities, phylogenetic signal in traits and phylogenetically corrected trait-trait associations, we used the phylogenetic hypothesis of Bouchenak-Khelladi et al. (2014), pruning it to retain only the species sampled in the present study. Since Bothriochloa radicans and Digitaria eriantha, two species sampled in the KNP, were not included in the phylogenetic tree, this reduced the data set to 66 species (370 individuals). Tree manipulation was done using functions in the ape package (Paradis et al. 2004), as implemented in $\mathrm{R}$ version 3.3.2 ( $\mathrm{R}$ Core Team 2016).

Phylogenetic signal and correlation between foliar traits

Both SLA and leaf tensile strength were log transformed to reduce skewness. Phylogenetic signal in both traits was assessed at the species level, using the mean value of traits measured for different individuals of each species. The package phytools (Revell 2012) was used to quantify phylogenetic signal using Pagel's (1999) $\lambda$ and by comparing the mean standardized contrast for each trait to a null distribution obtained by randomizing the tip values 999 times (Blomberg et al. 2003).

We then measured the correlation between SLA and leaf tensile strength at the individual level, using phylogenetic generalized least squares regression (PGLS) as implemented in the $\mathrm{R}$ package caper (Orme 2012), applying the $\lambda$ model to structure the residuals. Given that our trait data set contained multiple measurements per species (from multiple sites), whereas our phylogenetic tree represented each species by a single terminal, it was necessary to graft additional terminals onto the tree to accommodate replicate samples of each species. These terminals were added as polytomies whose crown nodes were positioned along the terminal branch length leading to the species in question, at an arbitrary depth of $1 \%$ of its length. The decision to represent intraspecific divergences as extremely recent was based on the assumption that conspecifics at Kruger share a common gene pool. Positioning the intraspecific polytomies deeper, at a depth of $10 \%$ of each species' terminal branch length, did not, however, qualitatively alter our results. 
Phylogenetic community structure

and composition

Phylogenetic structuring of the grass communities within each plot was quantified using the standardized effect size of the mean phylogenetic distance between species [SES ${ }_{\mathrm{MPD}}$; (Kembel et al. 2010)] relative to a null distribution based on 999 randomizations in which community richness was held constant. Values of this metric, which is -1 times the net relatedness index [NRI; (Webb et al. 2002)], and their associated significance levels were determined using the ses.mpd function in the picante package (Kembel et al. 2010). To test whether there was a general tendency towards phylogenetic clustering $\left(\mathrm{SES}_{\mathrm{MPD}}<0\right)$ or evenness $\left(\mathrm{SES}_{\mathrm{MPD}}>0\right)$ across all plots, we used a Wilcoxon signed-ranked test to assess whether the mean SES $S_{M P D}$ differed significantly from zero. In addition, to assess whether and how phylogenetic structuring was related to environmental variables, we tested the correlation of $\mathrm{SES}_{\mathrm{MPD}}$ to mean annual precipitation and whether it differed (one-way ANOVA) between plots situated on different geologies.

Focusing on five major subfamily/tribe-level PACMAD lineages (Andropogoneae, Aristidoideae, Cynodonteae, Eragrostideae, Paniceae; see Table S1 for details), we then determined whether the proportion of species representing each lineage in communities significantly differed among substrate types using Pearson's $\chi^{2}$ test. To assess whether individual lineages favour specific environmental conditions, we tested whether variation in the relative representation of lineages within plots was associated with differences in MAP (linear regression) or geology $(t$ test).

Relationships of leaf traits to environmental variables

We investigated how environmental variables influence traits by fitting linear regressions between average trait values in each grass community and MAP plus soil type as additive effects. We went a step further and asked whether trait turnover across communities is due to turnover in species composition or to leaf trait variation within species. To do so, we separated trait variation across grass communities into three components: variation that is due to species turnover, variation that is intraspecific, and variation that is due to the covariation between species turnover and intraspecific variation. This trait decomposition was done following the method of Lepš et al. (2011). It compares changes in community averages of traits calculated either using the mean trait of each species in all communities, which reflect species turnover only, or using changes in community averages of traits calculated from the traits actually observed in each community, which reflect both species turnover and within-species variability in traits.

Relationship of grazer density to leaf traits and grass composition

We tested how community-averaged values of SLA and leaf tensile strength correlated with the density of grazers. This was done by comparing the fit of alternative linear regression models in which grazer density was predicted by SLA, leaf tensile strength and their interaction. In a separate set of analyses, we finally tested whether grazer density was correlated with the relative proportion of species from different grass families using linear models.

To visualize relationships between environmental variables, grazer density and community-averaged values of leaf traits, we ran a principal component analysis (PCA) on values of all continuous variables for all grass communities sampled. Soil type, as a discrete variable, was not included in this ordination.

\section{Results}

Trait phylogenetic signal and trait-trait associations

Both log-transformed traits exhibited significant phylogenetic signal, whether assessed using Pagel's $\lambda$ or the variance of the standardized contrasts, regardless of whether polytomies representing multiple individuals within species were placed at the last $1 \%$ or $10 \%$ of terminal branches $(P<0.05$ for both indices and both polytomy depths, see trait distribution across the phylogeny on Fig. 2). In general, subfamily Aristidoideae displayed the lowest SLA and highest leaf tensile strength, while the opposite was true of tribe Paniceae (Fig. 2). Across all individuals sampled, the two traits were negatively correlated (Fig. 3). This was true both for individual polytomies placed at $1 \%$ 


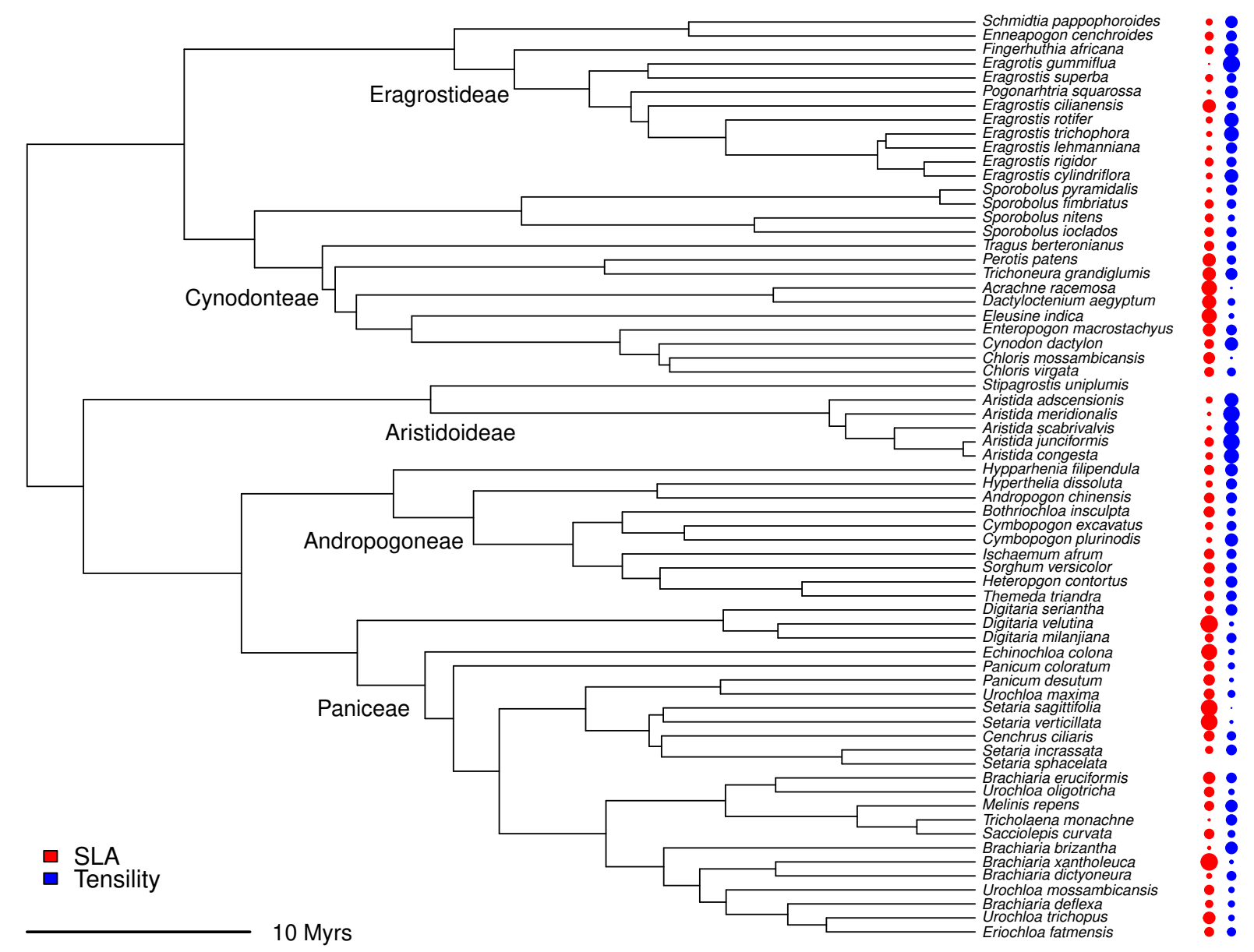

Fig. 2 SLA and leaf tensile strength of the 66 grass species sampled, plotted onto the phylogeny of Bouchenak-Khelladi et al. (2014). Logarithm transformed values of SLA (red dots)

$\left(\log -\log\right.$ slope $=-0.53, F_{1,357}=75.76, r^{2}=0.17$, $P<0.001)$ and at $10 \%$ of terminal branches $(\log -\log$ slope $=-0.54, \quad F_{1,357}=76.46, \quad r^{2}=0.17$, $\mathrm{P}<0.001)$. In both cases, the residuals of their relationship showed significant phylogenetic signal $(\lambda=0.60, P<0.001)$.

Phylogenetic community structure and composition

There was no general tendency for SES $\mathrm{SPD}_{\mathrm{MPD}}$ to differ significantly from 0 across the 37 communities sampled (one sample $t$ test, $t=-1.08$, df $=38$, $P=0.287$ ), with four communities showing significant phylogenetic clustering and one significant overdispersion. In addition, $\mathrm{SES}_{\mathrm{MPD}}$ was not and leaf tensile strength (blue dots) are shown for each species next to the corresponding tip of the phylogeny

correlated with either soil type $\left(F_{2,36}=0.91\right.$, $P=0.410, \quad$ adjusted $\quad r^{2}=0 \%$ ) nor MAP $\left(F_{2,37}=0.47, P=0.500\right.$, adjusted $\left.r^{2}=0 \%\right)$.

The five PACMAD clades sampled in this study were unevenly represented in the data set, with $35 \%$ of individuals belonging to Paniceae, 24\% to Eragrostideae, $20 \%$ to Andropogoneae, $10 \%$ to Cynodonteae, and the remaining 10\% to Aristidoideae (see Table S1). Clades were unequally distributed across soil types (Pearson's $\chi^{2}$ test: $\chi^{2}=18.8, \mathrm{df}=8$, $P=0.016$; Fig. 1). When looking at the influence of environmental variables on the representation of each clade separately, we found that the proportion of Paniceae species was significantly greater in communities on basalt and sedimentary soils than on granite soils $(P=0.011$ and 0.038 , respectively), although 


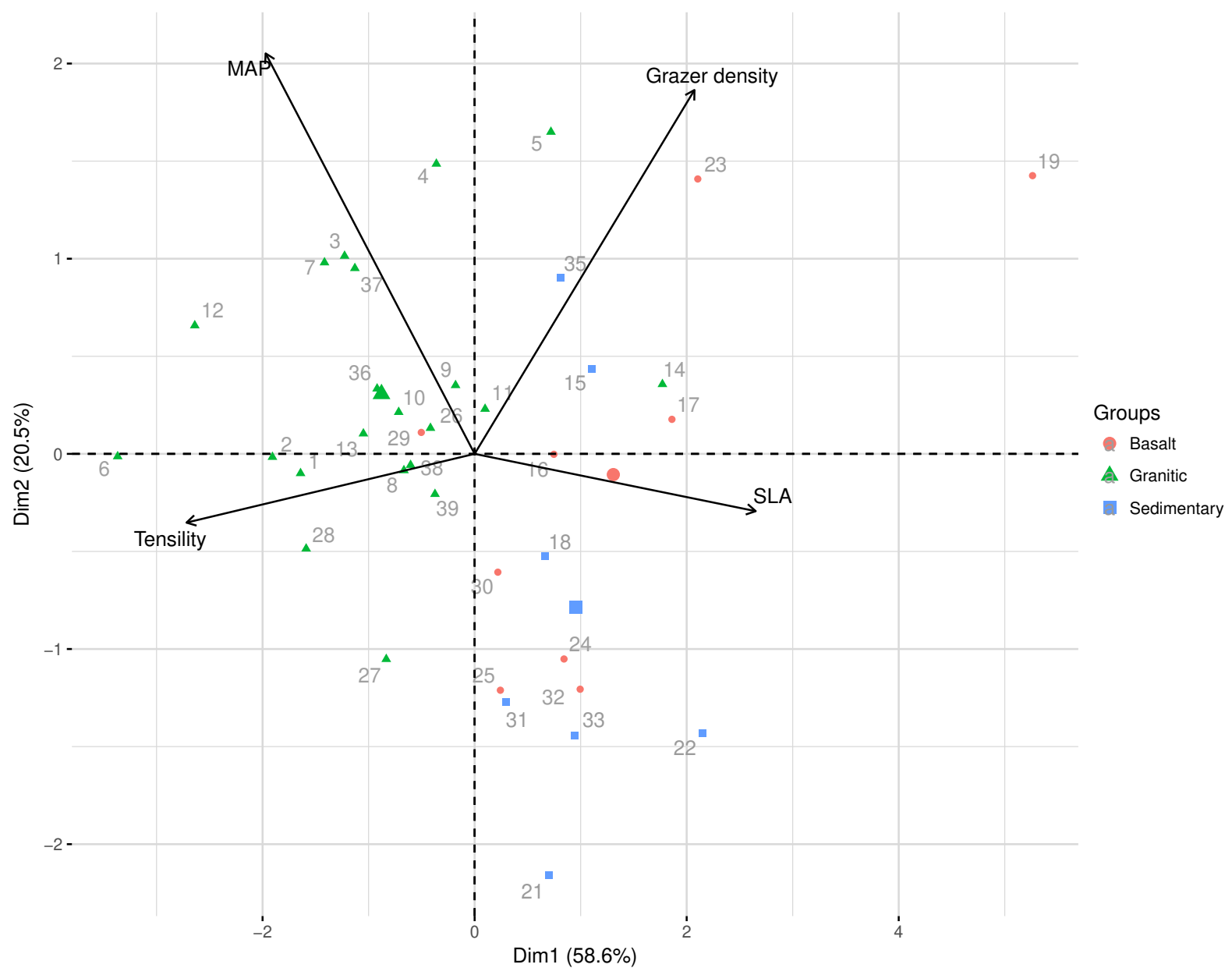

Fig. 3 A principal component analysis (PCA) of four continuous variables: SLA, leaf tensile strength, MAP, and grazer density. The percentage of variance explained is indicated for both axes. Each of the 37 communities is labelled and coloured

this did not correlate with MAP $(P=0.150$; overall model statistics: $F_{3,35}=2.69, P=0.061, r^{2}=12 \%$ ). By contrast, the proportion of Eragrostideae species was greater in granitic communities than in either basaltic $(P=0.019)$ or sedimentary communities $(P=0.008)$ and was negatively associated with MAP $\quad(P=0.028 ; \quad$ overall model statistics: $\left.F_{3,35}=2.96, \quad P=0.046, \quad r^{2}=13 \%\right)$. Aristidoideae showed a similar trend, being more prevalent on granite than on basalt $(P=0.057)$ and sedimentary soils $(P=0.013)$, its prevalence also being negatively associated with MAP $(P=0.064$; overall model statistics: $F_{3,35}=2.38, P=0.087, r^{2}=10 \%$ ). However, neither soil type nor MAP influenced the community-level representation of Andropogoneae according to its soil type. Three larger symbols show the mean position of the three soil categories in the PCA. Relationships between the four continuous variables and PC axes are shown with arrows

(overall model statistics: $F_{3,35}=1.01, P=0.400$, $\left.r^{2}=0 \%\right)$ and in Cynodonteae, there was only a marginally significant higher incidence on sedimentary soils $(P=0.071$; overall model statistics: $\left.F_{3,35}=2.20, P=0.11, r^{2}=9 \%\right)($ Table 1$)$.

\section{Trait-environment associations}

Variation in the community-average values of both traits was associated with environmental variables (Fig. 3). SLA was negatively associated with MAP $(P=0.020)$ but did not depend significantly on soil type $(P>0.100$ for all three pairwise comparison between soil types). Overall, environmental variables explained a large proportion of the variation in mean 
Table 1 Locations and descriptions of the 37 plots sampled in the Kruger National Park. Land systems, land types, MAP, and soil types are from Venter et al. (2003). Grazer density is from Smit et al. (2007)

\begin{tabular}{|c|c|c|c|c|c|c|c|c|}
\hline \multirow[t]{2}{*}{ Plot } & \multirow[t]{2}{*}{ Longitude } & \multirow[t]{2}{*}{ Latitude } & \multirow{2}{*}{$\begin{array}{l}\text { Land } \\
\text { system }\end{array}$} & \multirow[t]{2}{*}{ Land type } & \multirow[t]{2}{*}{ Type of soil } & \multirow{2}{*}{$\begin{array}{l}\text { Mean MAP } \\
\left(\mathrm{mm} \mathrm{year}^{-1}\right)\end{array}$} & \multicolumn{2}{|c|}{ Grazers density } \\
\hline & & & & & & & $\begin{array}{l}\text { Mean } \\
\left(\mathrm{kg} \mathrm{km}^{-2}\right)\end{array}$ & $\begin{array}{l}\mathrm{SD} \\
\left(\mathrm{kg} \mathrm{km}^{-2}\right)\end{array}$ \\
\hline 1 & 31.4316 & -25.0104 & Skukuza & Skukuza & Granitic & 575 & 599 & 859 \\
\hline 2 & 31.3769 & -24.9749 & Skukuza & Skukuza & Granitic & 625 & 124 & 205 \\
\hline 3 & 31.2315 & -25.1062 & Skukuza & Pretorius & Granitic & 625 & 1238 & 872 \\
\hline 4 & 31.312 & -25.1396 & Skukuza & Pretorius & Granitic & 625 & 1793 & 1180 \\
\hline 5 & 31.3762 & -25.1128 & Skukuza & Pretorius & Granitic & 625 & 2081 & 1328 \\
\hline 6 & 31.4176 & -25.1031 & Skukuza & Napi & Granitic & 575 & 840 & 753 \\
\hline 7 & 31.5522 & -25.1248 & Skukuza & Renosterk & Granitic & 625 & 1080 & 1189 \\
\hline 8 & 31.54 & -25.2525 & Skukuza & Makhuthwa & Granitic & 525 & 1046 & 929 \\
\hline 9 & 31.5536 & -25.3051 & Skukuza & Lwakahle & Granitic & 575 & 1098 & 1046 \\
\hline 10 & 31.5183 & -25.358 & Skukuza & Makhuthwa & Granitic & 625 & 626 & 836 \\
\hline 11 & 31.5094 & -25.3882 & Malelane & Malelane & Granitic & 625 & 645 & 810 \\
\hline 12 & 31.4425 & -25.4237 & Malelane & Malelane & Granitic & 675 & 283 & 378 \\
\hline 13 & 31.7084 & -25.3703 & Skukuza & Lwakahle & Granitic & 625 & 302 & 401 \\
\hline 14 & 31.772 & -25.193 & Skukuza & Randsprui & Granitic & 525 & 1831 & 1214 \\
\hline 15 & 31.8641 & -25.2842 & Vutome & Vutome & Sedimentary & 525 & 1749 & 1777 \\
\hline 16 & 31.9117 & -25.3135 & Satara & Satara & Basalt & 575 & 576 & 559 \\
\hline 17 & 31.9299 & -25.2115 & Satara & Satara & Basalt & 475 & 2019 & 1463 \\
\hline 18 & 31.8888 & -25.1728 & Vutome & Vutome & Sedimentary & 475 & 1226 & 1067 \\
\hline 19 & 31.9225 & -24.9559 & Satara & Satara & Basalt & 425 & 4099 & 5034 \\
\hline 20 & 31.957 & -24.6028 & Sabiepoort & Nwanetsi & Granitic & 375 & 567 & 584 \\
\hline 21 & 31.968 & -24.5215 & Sabiepoort & Nwanetsi & Granitic & 425 & 758 & 562 \\
\hline 22 & 31.8406 & -24.244 & Satara & Mavumbye & Basalt & 525 & 2849 & 1785 \\
\hline 23 & 31.736 & -24.04 & Letaba & Olifants & Basalt & 475 & 561 & 298 \\
\hline 24 & 31.5845 & -23.8758 & Letaba & Letaba & Basalt & 475 & 546 & 401 \\
\hline 25 & 31.4918 & -23.8734 & Phalaborwa & Malopeni & Granitic & 575 & 954 & 766 \\
\hline 26 & 31.3557 & -23.7936 & Phalaborwa & Mahlangen & Granitic & 475 & 896 & 699 \\
\hline 27 & 31.3812 & -23.5718 & Phalaborwa & Tsende & Granitic & 575 & 123 & 183 \\
\hline 28 & 31.369 & -23.4145 & Letaba & Mooiplaas & Basalt & 575 & 957 & 738 \\
\hline 29 & 31.3259 & -23.178 & Letaba & Shingwedz & Basalt & 525 & 564 & 1285 \\
\hline 30 & 31.2577 & -22.9229 & Phalaborwa & Dothole & Sedimentary & 425 & 1038 & 774 \\
\hline 31 & 31.2043 & -22.7904 & Letaba & Mooiplaas & Basalt & 425 & 993 & 988 \\
\hline 32 & 31.13 & -22.7489 & Bulweni & Maritheng & Sedimentary & 475 & 167 & 167 \\
\hline 33 & 31.7211 & -24.3909 & Vutome & Vutome & Sedimentary & 575 & 1649 & 1104 \\
\hline 34 & 31.584 & -24.3584 & Skukuza & Timbavati & Granitic & 575 & 1203 & 831.0 \\
\hline 35 & 31.6298 & -24.4706 & Skukuza & Muzandzen & Granitic & 625 & 1387 & 1272 \\
\hline 36 & 31.676 & -24.6505 & Skukuza & Nhlangule & Granitic & 575 & 631 & 628 \\
\hline 37 & 31.7179 & -24.9092 & Skukuza & Nhlangule & Granitic & 575 & 517 & 627 \\
\hline
\end{tabular}

$S D$ standard deviation 
SLA across communities $\left(r^{2}=039\right.$, overall model statistics: $\left.F_{3,36}=9.15, \quad P<0.001\right)$. Leaf tensile strength did not correlate significantly with MAP $(P=0.840)$ but was significantly higher on granite soils than on basalt $(P=0.003)$ and sedimentary soils $(P=0.019)$. Here again, environmental variables explained a large fraction of the variation in the mean leaf tensile strength at the community level $\left(r^{2}=0.33\right.$, overall model statistics: $F_{3,36}=7.47, P>0.001$ ).

When decomposing the variation in leaf traits across hierarchical levels, we found that a large portion of variation in both traits was due to intraspecific variability. For SLA, $17.8 \%$ of the variation was attributed to species turnover among communities, $50.4 \%$ was due to intraspecific variability, and the remaining $31.8 \%$ was due to the covariation between species turnover and intraspecific variability. For leaf tensile strength $36.8 \%$ of variation across communities was due to species turnover, $30.3 \%$ to intraspecific variability, and the remaining $32.9 \%$ to their covariation.

Relationship of grazer density to leaf traits and grass composition

When comparing the statistical fit of different models, we found support to be strongest for a model in which grazer density was explained by both communityaveraged SLA and tensile strength, as well as the interaction between these two variables $\left(\Delta \mathrm{AIC}_{\mathrm{c}}>3.9\right.$ with all other models; overall model statistics: $\left.F_{3,33}=7.27, P=0.00071\right)$. In this model, grazer densities generally increased with higher SLA and lower leaf tensile strength, being highest for a combination of these extreme trait values (Fig. 4). Jointly, these variables explained a large fraction of the variation in grazer densities across communities $\left(r^{2}=0.34\right)$. Adding MAP and soil type as covariates in this model led to a lower AIC (dAIC $=4.27$ ) with neither of these environmental variables correlating significantly with grazer densities $(P>0.52$ in both cases).

Grazer densities were not influenced by the proportion of Paniceae $\left(F_{1,35}=2.56, \quad P=0.012\right.$, $\left.r^{2}=0.04\right)$ and Cynodonteae species $\left(F_{1,35}=0.23\right.$, $\left.P=0.630, r^{2}=0.00\right)$ in grass communities, but increased with the proportion of Andropogoneae species $\left(F_{1,35}=5.39, \quad P=0.026, \quad r^{2}=0.11\right)$ and decreased with the proportions of both Aristidoideae

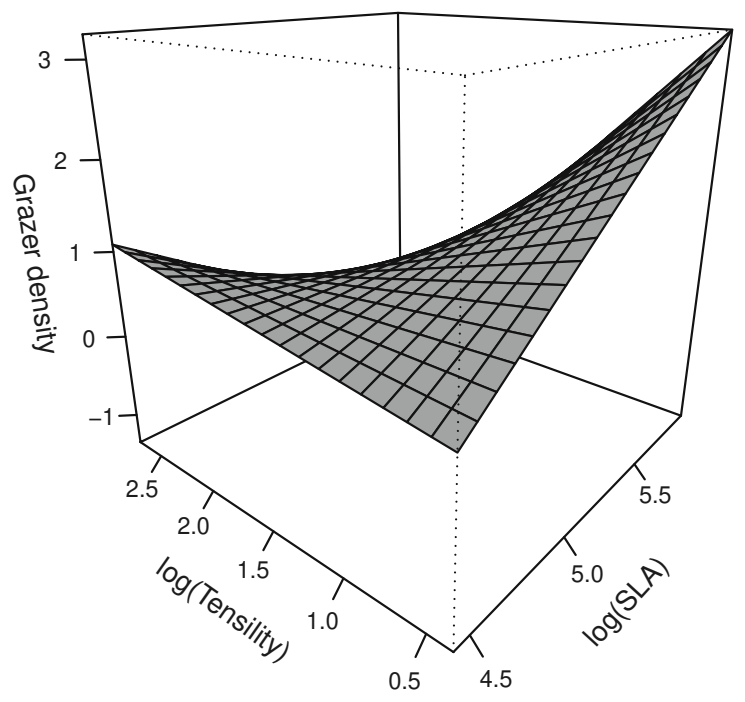

Fig. 4 Relationship between grazer density and grass functional traits. The grey surface shows the fitted response of the density of grazers at a given location as a function of the community-average SLA and leaf tensile strength of grass species as well as their interaction

$\left(F_{1,35}=5.47, \quad P=0.025, \quad r^{2}=0.11\right) \quad$ and $\quad$ Eragrostideae species $\quad\left(F_{1,35}=5.17, \quad P=0.029\right.$, $\left.r^{2}=0.10\right)$.

\section{Discussion}

Our results show that leaf functional traits of 66 grass species from 37 communities distributed across the KNP are associated with both soil type and MAP. In turn, the community means of these traits are highly correlated with grazer densities in this savanna ecosystem.

Effect of rainfall and soil type on leaf functional traits

Although the negative relationship between SLA and leaf tensile strength observed in this study is not ubiquitous (Wigley et al. 2016), such a relationship is expected given the dependence of both these traits on leaf fibre density. The association of both traits with MAP and soil type is equally expected given that these traits strongly influence leaf lifespan and resilience to damage. Indeed, MAP and soil type together had a large influence on leaf traits of the KNP grasses, explaining more than $33 \%$ of their variation in both 
cases. Consistent with earlier studies (Wright et al. 2001), grasses growing on less fertile granite soils had higher leaf tensile strengths than those occurring on the higher nutrient basalts, a pattern that is presumably attributable to the nutrient conservation benefits associated with high leaf tensile strength (Wright and Westoby 2003; Pérez-Ramos et al. 2012). Despite the relatively small MAP range in our study (400 to $750 \mathrm{~mm} \mathrm{year}^{-1}$ ), we found a negative correlation between mean SLA at the community level and rainfall. These results are similar to those reported for Stipa-dominated grasslands in Northern China (Liu et al. 2017). In these communities, this pattern was interpreted as reflecting an adaptive response to drought (Liu et al. 2017) and we favour a similar interpretation here. These results may, however, confound the influence of soil fertility at our study site with several studies revealing strong relationships between soil fertility and SLA (Craine et al. 2001; Al Hadj Khaled et al. 2005; Ordoñez et al. 2009). While the overall relationship between substrate and average SLA at the community level was not significant, there is a weak tendency for SLA to be lower on the granite than on the basalt $(P=0.056)$ and sedimentary soils $(P=0.270)$.

The relationship between MAP and SLA may, therefore, be underpinned by the fertility of the underlying soils suggesting that soil type and MAP jointly determine grass leaf traits in the KNP.

Phylogenetic distribution of grass species

Overall, our study provides limited evidence of phylogenetic structure in the grass communities studied with only four out of 37 communities exhibiting significant phylogenetic clustering and only one significant over dispersion. We did, however, find that some of the major grass clades were unevenly distributed between soil types and along the rainfall gradient. For example, while Paniceae were more prevalent on basaltic and sedimentary soils, Aristidoideae and Eragrostideae were more prevalent on granite, the latter two also declining with increasing rainfall. Interestingly, where previous authors have found strong associations of Andropogoneae with moist, infertile environments (Visser et al. 2012; Forrestel et al. 2015), we found no evidence of such an association. This is most likely a consequence of our study covering much narrower environmental gradients than these previous studies, which covered much broader geographic areas. There is also a large range of phenotypic diversity within each of these clades, and, as such, our results should be taken with caution.

As environmental gradients influence species distributions and our results show a strong phylogenetic signal in key functional traits, the distributions of the major lineages present in the KNP are likely a consequence of traits associated with environmental filtering (Scholtz et al. 2014). Therefore, the low SLA and high tensile strength of aristidoid grasses may account for their greater prevalence in low-fertility, granitic communities. In contrast, the high SLA and low tensile strength of Paniceae likely explain the association of this tribe with more fertile, basalt settings.

We did, however, find that a large fraction of leaf trait variation across grass communities of the KNP is due to intraspecific variability while species turnover among communities accounts for less variation in leaf traits. This cautions against excessive reliance on species inventories as a proxy for the functional characteristics of grass communities, and suggests that we should improve our understanding of the links between the dynamics of individual plants and ecosystem functioning (Ackerly and Cornwell 2007).

\section{Relationship between grass traits and grazer} density

At the community level, we found that grazer densities in the KNP were highest on sites characterized by low leaf tensile strength (O'Reagain 1993), and high SLA, regardless of rainfall and soil type. These relationships were strong, with these foliar traits jointly explaining $34 \%$ of the variation in grazer densities across the KNP. Given the strong negative association of grazer density with leaf traits, the observation of low grazer densities in sites with high frequencies of Aristidoideae and Eragrostideae is unsurprising. Aristidoideae are not palatable for large herbivores because of their high leaf tensile strength, and high epidermal silica densities (Bouchenak-Khelladi et al. 2009). This observation is consistent with the hypothesis that some $\mathrm{C}_{4}$ grass lineages, such as Aristidoideae, have evolved less palatable leaves as a defence against herbivory (McNaughton and Georgiadis 1986; BouchenakKhelladi et al. 2009). These findings are in line with 
the distinction between grazing lawns (highly palatable) and tall-grass (less palatable) communities (Hempson et al. 2015), and suggest that these two types of communities differ not only in taxonomic composition but also in functional traits.

While we have demonstrated a strong correlation between grass foliar traits and grazer densities, the causal directionality underpinning this relationship remains unresolved. On the one hand, leaf traits determine both the quality and quantity of available forage (Wright et al. 2001; Pontes et al. 2007; Duru et al. 2009) and should thus influence grazer densities. On the other hand, grazers may exert a positive feedback on leaf traits. For example, high grazer densities are likely to have a positive effect on community-level grass foliar traits through the effects of their faeces in enhancing soil fertility and of their defoliation in selecting for rapid regrowth (Wright et al. 2001; Hempson et al. 2015). Although several studies have demonstrated the associations between grazing ungulates and the moisture or nutrient content of grasses (MacNaughton 1983; Holdo et al 2009; Augustine and MacNaughton 2006), the effects of grazers on specific grass traits such as SLA and leaf tensile strength remain poorly understood (van der Plas et al. 2016).

More generally, there is also an extensive literature on the extent to which top-down (herbivory and fire) and bottom-up (substrate and rainfall) factors structure plant communities in savanna ecosystems (e.g. February et al. 2013; Archibald and Hempson 2016; Lehmann et al. 2014; Forrestel et al. 2015; February and Higgins 2016). An understanding of the interactions between top-down and bottom-up controls, and how these may vary in space and time does, however, remain elusive. Understanding how these interactions influence functional traits at the community level is, however, essential for an improved understanding of African savanna vegetation structure. Unfortunately, the resolution of our herbivore data does not allow us to assess the relative importance of top-down vs. bottom-up controls on grass communities of the KNP. Such a task would at least require fine-scale measurements of herbivore densities (in contrast to the $3 \times 3 \mathrm{~km}$ resolution of our data), given that herbivore communities show small-scale spatial heterogeneity (Burkepile et al. 2016) and respond to very small-scale variation in plant communities (Cromsigt and Olff 2008). But this important question would be even better dealt with using time-series measurement of both grazer densities and grass functional traits and/or manipulative experiments.

\section{Conclusion}

We have demonstrated complex interactions between climate, soils, and grazer densities in relation to grass functional traits in the KNP. We found that the distribution and density of grazers is associated with the foliar traits of the associated grass communities, possibly via the influence of MAP and soil fertility on both SLA and leaf tensile strength, and consequently on leaf palatability of grass communities. This has significant implications for our understanding of the evolutionary processes that have led to the expansion of $\mathrm{C}_{4}$ grasslands and savannas worldwide. However, the resolution of our herbivore data does not allow for a clear determination of the extent to which top-down controls influence this association, and at what levels.

Acknowledgements We are grateful to $M$. van der Bank for logistical support, Izak Smit for comments on the manuscript and for making the grazer data available, and to four anonymous reviewers for helpful comments on the manuscript. YBK was supported by a Smuts Postdoctoral Fellowship from the University of Cape Town. FCB acknowledges a grant from the Claude Leon foundation. All authors declare no conflict of interest.

\section{References}

Ackerly DD, Cornwell W (2007) A trait-based approach to community assembly: partitioning of species trait values into within-and among-community components. Ecol Lett 10:135-145

Al Haj Khaled R, Duru M, Theau JP, Plantureux S, Cruz P (2005) Variation in leaf traits through seasons and $\mathrm{N}$-availability levels and its consequences for ranking grassland species. J Veget Sci 16:391-398

Archibald S, Hempson GP (2016) Competing consumers: contrasting the patterns and impacts of fire and mammalian herbivory in Africa. Philos Trans R Soc B 371:20150309

Archibald S, Bond WJ, Stock WD, Fairbanks DHK (2005) Shaping the landscape: fire-grazer interactions in an African savanna. Ecol Appl 15(1):96-109

Augustine DJ, McNaughton SJ (1998) Ungulate effects on the functional species composition of plant communities: herbivore selectivity and plant tolerance. J Wildl Manage 62:1165-1183

Augustine DJ, McNaughton SJ (2006) Interactive effects of ungulate herbivores, soil fertility, and variable rainfall on ecosystem processes in a semi-arid savanna. Ecosystems 9:1242-1256 
Augustine DJ, McNaughton SJ, Frank DA (2003) Feedbacks between soil nutrients and large herbivores in a managed savanna ecosystem. Ecol Appl 13:1325-1337

Blomberg SP, Garland T Jr, Ives AR (2003) Testing for phylogenetic signal in comparative data: behavioral traits are more labile. Evolution 57:717-745

Bouchenak-Khelladi Y, Verboom GA, Hodkinson TR et al (2009) The origins and diversification of $\mathrm{C} 4$ grasses and savanna-adapted ungulates. Global Change Biol 15:2397-2417

Bouchenak-Khelladi Y, Slingsby JA, Verboom GA, Bond WJ (2014) Diversification of C4 grasses (Poaceae) does not coincide with their ecological dominance. Am J Bot 101:300-307

Burkepile DE, Thompson DI, Fynn RW et al (2016) Fire frequency drives habitat selection by a diverse herbivore guild impacting top-down control of plant communities in an African savanna. Oikos 125:1636-1646

Cingolani AM, Posse G, Collantes MB (2005) Plant functional traits, herbivore selectivity and response to sheep grazing in Patagonian steppe grasslands. J Appl Ecol 42:50-59

Craine JM, Froehle J, Tilman DG, Wedin DA, Chapin FS III (2001) The relationships among root and leaf traits of 76 grassland species and relative abundance along fertility and disturbance gradients. Oikos 93:274-285

Cromsigt JP, Olff H (2008) Dynamics of grazing lawn formation: an experimental test of the role of scale-dependent processes. Oikos 117:1444-1452

Cromsigt JP, Prins HH, Olff H (2009) Habitat heterogeneity as a driver of ungulate diversity and distribution patterns: interaction of body mass and digestive strategy. Divers Distrib 15:513-522

Duru M, Adam M, Cruz P et al (2009) Modelling above-ground herbage mass for a wide range of grassland community types. Ecol Model 220:209-225

East R (1984) Rainfall, soil nutrient status and biomass of large African savanna mammals. Afr J Ecol 22:245-270

February EC, Higgins SI (2010) The distribution of tree and grass roots in savannas in relation to soil nitrogen and water. S Afr J Bot 76:517-523

February EC, Higgins SI (2016) Rapid leaf deployment strategies in a deciduous savanna. PLoS ONE 11:e0157833

February EC, Higgins SI, Bond WJ, Swemmer L (2013) Influence of competition and rainfall manipulation on the growth responses of savanna trees and grasses. Ecology 94:1155-1164

February EC, Coetsee C, Cook GD, Ratnam J, Wigley B (2019) Physiological traits of woody species: adaptations to resource availability. In: Scogings PF, Sankaran M (eds) Savanna woody plants and large herbivores. Wiley, New York, pp 309-329

Flores O, Garnier E, Wright IJ et al (2014) An evolutionary perspective on leaf economics: phylogenetics of leaf mass per area in vascular plants. Ecol Evol 4:2799-2811

Forrestel EJ, Donoghue MJ, Smith MD (2015) Functional differences between dominant grasses drive divergent responses to large herbivore loss in mesic savanna grasslands of North America and South Africa. J Ecol 103:714-724

Franks SJ, Pratt PD, Dray FA, Simms EL (2008) No evolution of increased competitive ability or decreased allocation to defense in Melaleuca quinquenervia since release from natural enemies. Biol Invasion 10:455-466

Garnier E, Shipley B, Roumet C, Laurent G (2001) A standardized protocol for the determination of specific leaf area and leaf dry matter content. Funct Ecol 15:688-695

Grant C, Scholes M (2006) The importance of nutrient hot-spots in the conservation and management of large wild mammalian herbivores in semi-arid savannas. Biol Conserv 130:426-437

Hempson GP, Archibald S, Bond WJ et al (2015) Ecology of grazing lawns in Africa. Biol Rev 90:979-994

Holdo RM, Holt RD, Fryxell JM (2009) Opposing rainfall and plant nutritional gradients best explain the wildebeest migration in the Serengeti. Am Nat 173:431-445

Holdo RM, Nippert JB, Mack MC (2018) Rooting depth varies differentially in trees and grasses as a function of mean annual rainfall in an African savanna. Oecologia 186:269-280

Kembel SW, Cowan PD, Helmus MR et al (2010) Picante: R tools for integrating phylogenies and ecology. Bioinformatics 26:1463-1464

Kruger J, Reilly B, Whyte I (2008) Application of distance sampling to estimate population densities of large herbivores in Kruger National Park. Wildl Res 35:371-376

Lehmann CER, Parr CL (2016) Tropical grassy biomes: Linking ecology, human use and conservation. Philos Trans R Soc B 371:20160329

Lehmann CE, Anderson TM, Sankaran M et al (2014) Savanna vegetation-fire-climate relationships differ among continents. Science 343:548-552

Lepš J, de Bello F, Šmilauer P, Doležal J (2011) Community trait response to environment: disentangling species turnover vs intraspecific trait variability effects. Ecography 34:856-863

Liu H, Xu Q, He P, Santiago LS, Yang K, Ye Q (2015) Strong phylogenetic signals and phylogenetic niche conservatism in ecophysiological traits across divergent lineages of Magnoliaceae. Sci Rep UK 5:12246

Liu M, Wang Z, Li S, Lü X, Wang X, Han X (2017) Changes in specific leaf area of dominant plants in temeperate grasslands along a 2500-km transect in Northern China. Sci Rep 7:10780

Martens P, de V. Booysen P (1968) A tensilmeter for the measurement of the tensile strength of grass leaf blades. Afr $\mathrm{J}$ Range For Sci 3:51-56

McNaughton SJ (1983) Serengeti grassland ecology: the role of composite environmental factors and contingency in community organization. Ecol Monogr 53:291-320

McNaughton S, Georgiadis NJ (1986) Ecology of African grazing and browsing mammals. Annu Rev Ecol Syst 17:39-66

Medina E (1993) Mineral nutrition: tropical savannas. In: Behnke HD, Lüttge U, Esser K, Kadereit JW, Runge M (eds) Progress in Botany/Fortschritte der Botanik. Springer, Berlin, pp 237-253

Ordoñez JC, Van Bodegom PM, Witte JPM, Wright IJ, Reich PB, Aerts R (2009) A global study of relationships between leaf traits, climate and soil measures of nutrient fertility. Global Ecol Biogeogr 18:137-149 
Orme D (2012) The Caper package: comparative analysis of phylogenetics and evolution in R. Available: http://cran.rproject.org/web/packages/caper

O'Reagain PJ (1993) Plant structure and the acceptability of different grasses to sheep. J Range Manag 46:232-236

Pagel M (1999) Inferring the historical patterns of biological evolution. Nature 401:877

Paradis E, Claude J, Strimmer K (2004) APE: analyses of phylogenetics and evolution in $\mathrm{R}$ language. Bioinformatics 20:289-290

Pérez-Ramos IM, Roumet C, Cruz P, Blanchard A, Autran P, Garnier E (2012) Evidence for a 'plant community economics spectrum'driven by nutrient and water limitations in a Mediterranean rangeland of southern France. J Ecol 100:1315-1327

Pontes LDAS, Soussana JF, Louault F, Andueza D, Carrere P (2007) Leaf traits affect the above-ground productivity and quality of pasture grasses. Funct Ecol 21:844-853

R Core Team (2016) R: a language and environment for statistical computing. R Foundation for Statistical Computing, Vienna, Austria, p 2014

Revell LJ (2012) phytools: an R package for phylogenetic comparative biology (and other things). Methods Ecol Evol 3:217-223

Sankaran M, Hanan NP, Scholes RJ et al (2005) Determinants of woody cover in African savannas. Nature 438:846-849

Scholes R (1990) The influence of soil fertility on the ecology of southern African dry savannas. J Biogeogr 17:415-419

Scholes R, Archer SR (1997) Tree-grass interactions in savannas. Ann Rev Ecol Syst 28:517-544

Scholtz R, Kiker G, Smit I, Venter F (2014) Identifying drivers that influence the spatial distribution of woody vegetation in Kruger National Park, South Africa. Ecosphere 5:1-12

Smit IP, Grant CC, Devereux BJ (2007) Do artificial waterholes influence the way herbivores use the landscape? Herbivore distribution patterns around rivers and artificial surface water sources in a large African savanna park. Biol Conserv 36:85-99
Turpie J, Crowe T (1994) Patterns of distribution and diversity of larger mammals in Africa. S Afr J Zool 29:19-31

van der Plas F, Howison RA, Mpanza N, Cromsigt JP, Olff H (2016) Different-sized grazers have distinctive effects on plant functional composition of an African savannah. J Ecol 104:864-875

Venter FJ (1990) A classification of land for management planning in the Kruger National Park. University of South Africa, PhD

Venter FJ, Scholes RJ, Eckhardt HC (2003) The abiotic template and its associated vegetation pattern. In: DuToit JT, Rogers $\mathrm{KH}$, Biggs HC (eds) The Kruger experience. Ecology and management of savanna heterogeneity. Island Press, Washington, pp 519-528

Visser V, Woodward FI, Freckleton RP, Osborne CP (2012) Environmental factors determining the phylogenetic structure of C4 grass communities. J Biogeogr 39:232-246

Webb CO, Ackerly DD, McPeek MA, Donoghue MJ (2002) Phylogenies and community ecology. Annu Rev Ecol Syst 33:475-505

Wigley BJ, Slingsby JA, Díaz S, Bond WJ, Fritz H, Coetsee C (2016) Leaf traits of African woody savanna species across climate and soil fertility gradients: evidence for conservative versus acquisitive resource-use strategies. J Ecol 104:1357-1369

Wright IJ, Westoby M (2003) Nutrient concentration, resorption and lifespan: leaf traits of Australian sclerophyll species. Funct Ecol 17:10-19

Wright IJ, Reich P, Westoby M (2001) Strategy shifts in leaf physiology, structure and nutrient content between species of high-and low-rainfall and high-and low-nutrient habitats. Funct Ecol 15:423-434

Publisher's Note Springer Nature remains neutral with regard to jurisdictional claims in published maps and institutional affiliations. 